\title{
Cultural Heritage Tourism as an Innovative Catalyst of Local Development: Strategies and Actions
}

\author{
Esraa Fathy Alhadad and Tinatin Meparishvili
}

\begin{abstract}
It has always been a matter of dispute, whether tourism has a positive effect on a cultural heritage site or not; it is a topic that has been recently gaining a lot of attention of scholars and policy-makers alike. When we initiate this discussion, it is important to think about the following questions: why was the cultural heritage site created primarily? Was it intended to be an abstract object, something maintained by locals for its artistic/cultural/historic values or was it originally meant to be exploited and used by the community? What is the central focus for us, as the conservators and heritage managers: the well-being of the community by maintenance and sustainable development of the heritage site or preservation of the site as a distant object, away from the locals and abandoned of its original use? Is the focus the Site or the Community, or the Site for the Community and other way around? Where is the golden mean between advantageous and disadvantageous tourism?

This paper will answer the questions, arisen in the paragraph above, by providing a successful case study about the heritage sites in Georgia, in a borderline between Europe and Asia, discussing how tourism transformed communities, decreasing unemployment level, improving accessibility of heritage sites, developing infrastructure and raising awareness of the cultural value of regions.

As a recommendation, the paper will discuss how the previous experiences can be used for boosting sustainable tourism development on the Elephantine Island in Aswan for the favor of the community by recommending the appropriate strategies and actions to achieve a successful sustainable development.
\end{abstract}

\section{Keywords}

Heritage Site, Sustainable Development, Cultural Tourism, Bilbao Effect, Community.

\section{Introduction}

As a goal of sustainable tourism development, destinations and cultural heritage resources that used by both the tourists and the local community in the heritage area are indeed two essential aspects. The idea of sustainable development plans has to be linked to community development in three main different aspects: economically, socio-culturally and environmentally. Keep in mind that none of the ideal development projects should harm the community in any of the previous mentioned three aspects. The purpose of the paper is to address the cultural heritage tourism definition and importance for the site management and community development. Then it goes through the benefits or advantages of cultural tourism on the community and how this would affect the development of the quality of life, of the people attached to the heritage site, economically, socio-culturally and environmentally. On the other hand, the paper also tackles the negative influences of tourism environmentally, socio- culturally and economically.

Then the paper addresses Mestia as Case Study, which is located in Georgia, as a proof on one of the successful sustainable cultural tourism development cases. The reasons for choosing this case study were mainly both the development vision and the specific Master Planit had, as it will be discussed later in this paper. This is followed by the case of Aswan Island (Elephantine), as the main case addressing the situation analysis, goals and strategies then addressing the risks management and finally the outcomes and outputs. 


\section{Cultural Heritage Tourism}

At any tourist destination, cultural and heritage tourism are very important attractions. Moreover, they are major factors in economic and urbanization. ${ }^{1}$ According to János, defining cultural tourism is very difficult, as there are many definitions for this term, especially that some of them focuses on the attraction aspect of it; experiences while others on the geographical places of the site. ${ }^{2}$ Cultural tourism was defined by the ICOMOS (International Scientific Committee on Cultural Tourism) as "that activity which enables people to experience the different ways of life of other people, thereby gaining at first hand an understanding of their customs, traditions, the physical environment, the intellectual ideas and those places of architectural, historic, archaeological or other cultural significance which remain from earlier times. Cultural tourism differs from recreational tourism in that it seeks to gain an understanding or appreciation of the nature of the place being visited". ${ }^{3}$

The term had various definitions as well by many authors and organizations. The National Trust for Historic Preservation, for instance, defined the term as "travel to experience the places, artifacts and activities that authentically represent the stories and people of the past and present, including cultural historic and natural resources. As a strong tool in building communities, cultural heritage tourism plays an important role in building the capacity and knowledge, strengthening the social inclusion, as well as enhancing the social capital and pride. One important aspect here is that the entire community should be involved in order to get effective results out of any developing project. In other words, to have a successful development project, it has to attract the tourists, preserve the site and engage the locals. Practically speaking, any one of these three mentioned elements can get out of balance and cause less outcomes. ${ }^{4}$

One of the important challenges facing cultural heritage tourism is the involvement of different stakeholders in the development or planning. These key actors can simply be divided into four main factors including, the public sector, private sector, NGO's and communities. Achieving the aim of making a touristic site as a destination requires different resources management, stakeholder management, implementation, etc. Among the obstacles that can affect achieving sustainable heritage destinations are: the lack of financial resources, poor planning, lack of community involvement, and lack of support for heritage conservation, etc. ${ }^{5}$

As two important components of development, tourism and culture had been two integrated concepts that cannot be separated. On one hand, sustainable tourism development requires the cooperation and involvement of all the key Stakeholders. Consistent implementation for an appropriate plan depends on the available resources, values, goals, aims of the development project with the necessary strategies and actions. ${ }^{6}$

\section{Benefiting of Tourism}

As a growing industry and a valuable sector worldwide that gains high attention from different national and international institutions, tourism has several benefits for the host communities, the touristic site and the country. Among these benefits are: increasing the high number of employment, developing the infrastructure, raising up the economic level of the locals, improving the social level and capacity- building of people and positively developing the site itself. The development is usually in different aspects, rather environmentally, economically, socially, culturally or in the physical aspects. On the other hand, different transformations usually take place regarding the transformation of values, population structures, types of occupations, the traditional lifestyles, etc. ${ }^{7}$

One of the golden recent trends in the world is the community- based tourism, which manages tourism by communities for

\footnotetext{
${ }^{1}$ Alzua Aurkene, et al., "Cultural and Heritage Tourism: Identifying niches for International Travelers", The Journal of Tourism Studies 9, no. 2, (2009): 2.

${ }^{2}$ CJános Csapó, “The Role and Importance of Cultural Tourism in Modern Tourism Industry”, in Kasimoglu, Murat (ed.), Strategies for Tourism Industry Micro and Macro Perspectives, Hungary (2012): 204.

${ }^{3}$ ICOMOS Charter for Cultural Tourism, Draft (April 1997).

${ }^{4}$ Robert. McNulty and Russell, Koff. “About partners for livable communities”, Washington, DC, (2014): 6, 15, 17.

${ }^{5}$ Walter Jamieson, The Challenges of Sustainable Community Cultural Heritage Tourism, Asian Institute of Technology, Bangkok, Thailand, (2000): 5.

${ }^{6}$ Mike Robinson and David Picard. "Tourism, Culture and Sustainable Development, Programme" "Culture, tourism, development", Division of cultural policies and intercultural dialogue, Culture Sector, UNESCO, France, (2006): 16

${ }^{7}$ Thryambakam Potukuchi, "Impact of Tourism on Community Development and Sustainability in Maredumilli, East Godavari District of Andhra Pradesh- A Case Study", Global Journal of Management and Business Studies 3, no. 9 (2013): 1013.
} 
tourist destinations. In general, the management in this type of tourism takes place by the communities and most of the profits go directly back to the people ${ }^{8}$.

Another different way to divide the benefits is to divide it into tangible and intangible. Tangible benefits arelike job opportunities, economic revenues, infrastructure development, creative industry flourishing and finally increase people income and country revenues etc. ${ }^{9}$ Intangible benefits link the next generation with their property, improve social levels, enhance the sense of belonging and identity to their heritage, capacity building, and increase knowledge quality of life, etc. ${ }^{10}$

Economic and socio- cultural benefits of tourism to the locals will be the two focused approaches in this paper. Economically, the impacts are usually noticed in the new job opportunities offered in the sector as well as attracting new investments for the locals and increasing the revenues of the country. On the other hand, this can improve the infrastructure through the different development projects, increase the economic level of the community and improve the quality of life. ${ }^{11}$ Various previous studies showed that economic benefits in many countries usually go to the tourism development or different types of stakeholders rather than the community members. ${ }^{12}$ According to Nayomia and Gnanapala, "tourism can serve as a supportive force for peace, foster pride in cultural traditions and help avoid urban relocation by creating local jobs" 13 .

\section{Red Flags of Tourism}

As any other sector, tourism has two sides: positive and negative influences. These influences can affect the site or the community. These influences can simply be divided into three main categories: environmental, economic and socio- cultural impacts. The relationship between the environment and tourism can be described as a complex one, due to the several activities which take place and can cause some effects. Among these effects are the air pollution, vandalism, noise, solid waste, Aesthetic Pollution, litter, etc. ${ }^{14}$

Socio cultural negative influences of tourism are usually noticed when it's poor planed by the different key stakeholders and the site manager. The negative effects can be presented in the tradition, identity and cultural practices of the local people. Sometimes tensions and conflicts increase between the community and the tourists, for fear that tourism would do some changes affecting the indigenous identity, values systems, authenticity, behavior, etc. However, the negative impacts are not in high level compared to the positive ones. ${ }^{15}$

Tourism is a sensitive industry influenced by any changes nationally or internationally, such as the price changes, the political instability, etc. The economic effects can be noticed for instance in the seasonal employment, since the chances for people depend on the seasons of tourism. This affects the prices and the economic level of the locals that can be solved by considering the sustainable solution and good planning between the locals and the other key stakeholders. ${ }^{16}$

\section{Mestia Case Study}

Numerous cases around the globe can prove the benefit of sustainable cultural tourism that the community experiences in and post development phases of tourism regional development process. It is very well demonstrated in Mestia case study. The

\footnotetext{
${ }^{8}$ Potukuchi, "Impact of Tourism on Community Development and Sustainability in Maredumilli, East Godavari District of Andhra Pradesh- A Case Study": 1016.

${ }^{9}$ Fariborz Aref, “Community Leaders' Perceptions toward Tourism Impacts and Level of Community Capacity Building in Tourism Development”, Journal of Sustainable Development 2, no. 3, (November 2009): 208-213.

${ }^{10}$ Esraa Alhadad. “Stakeholder Involvement in Heritage Site Management”, Master Thesis, BTU- Cottbus, Germany and HU- Egypt, (2015): 71.

${ }^{11}$ Speno, Lynn (ed.). Heritage Tourism Handbook: A How-to-Guide for Georgia, Historic Preservation Division, (2010): 3.

${ }^{12}$ Slavi Slavov “Impacts of Tourism on The Local Community”, Scientific Review of Physical Culture 5, issue 3, National Sports Academy “Bulgaria, 59.

${ }^{13}$ Nayomi Geethika and Gnanapala, W.K. Athula "Socio-Economic Impacts on Local Community through Tourism Development with Special Reference to Heritance Kandalama”, Tourism, Leisure and Global Change2 (2015): TOC-57.

${ }^{14}$ Ugur Sunlu. "Environmental Impacts of Tourism", in Camarda D. (ed.), Grassini L. (ed.). Local resources and global trades: Environments and agriculture in the Mediterranean region, (2003): 263

${ }^{15}$ Slavi SLAVOV, 5 .

${ }^{16}$ Fateme Ardahaey. "Economic Impacts of Tourism Industry", International Journal of Business and Management 6, no. 8, (August 2011): 212, www. cesenet.org/ijbm. (last accessed: January 12, 2018)
} 
regional development plan that was implemented successfully was completed in 2011 in Mestia, in the country of Georgia. ${ }^{17}$ The country, which is located on the crossroad of East and West and represents a borderline between Europe and Asia, is rich in its cultural and nature resources. ${ }^{18}$ If all the potential is united and directed to the right customer sector, the success must be guaranteed.

To better understand the cultural, economic and political environment of the city of Mestia, before diving into the implementation of tourism regional development project, and to correctly apprehend the outcomes of it, background story should be briefly analyzed.

\section{BriefHistory of Mestia}

Mestia that has about 2000 inhabitants is a regional center of the north-west mountainous province of Georgia-Upper Svaneti. It is located 1500 meters above the sea level, being bordered by the Caucasus Mountains on the north, and the Svaneti ridge on the south. ${ }^{19}$ The middle mountain (low belt) climate is characteristic to this region. ${ }^{20}$ This factor conditioned the development of stockbreeding and agricultural sector. Besides, the mountain slopes provide enough possibilities to boost skiing tourism in Mestia. Though the distance between the capital city Tbilisi and Mestia is about 463 kilometers that takes 7.5 hours to cover by car, ${ }^{21}$ the town has always been an attractive place for tourists, because of its picturesque nature. ${ }^{22}$

Svan people that inhabit the region represent one of the oldest Georgina tribes, who influenced the formation of Georgians. The spoken language there is Svanuri, one of four Georgian language groups. As the province has always been naturally well protected by mountains, Svanuri has not been influenced by any other languages and has been preserved originally as it was spoken when Svans settled in the area. ${ }^{23}$ Besides the language, the people here still practice traditional lifestyle and have kept the customs that are centuries old. Upper Svaneti has one of the best examples of Georgian architecture and ethnography. The place that has well preserved civic, religious and defensive structures dating back to the medieval ages, has also maintained the original settlement and land-use pattern.

Therefore, UNESCO has included it in its World Heritage List under the criteria iv and v. ${ }^{24}$

\section{Political and Economic Situation in Post-Soviet Georgia}

Georgia, as one of the 15 republics of the Soviet Union ${ }^{25}$, has suffered the aftereffects of the vices of the regime. ${ }^{26}$ After signing the Independence Act in 1991, the country was officially separated from the USSR and has declared its freedom. ${ }^{27}$ The path towards the political and economic stability was not smooth. The soviet planned economy had to be converted into market economy, as it was no longer compatible with the capitalist world. The new reforms were to be implemented, yet no methodology existed that the economists could use as a guideline. ${ }^{28}$ The inflation that devastated the citizens' social state in early $90 \mathrm{~s}$ was only worsening the condition of Georgians, as people were also facing a civil war and natural disasters. Thousands of people were dislocated from their original places of inhabitance due to the fact that their towns and villages were occupied by Russia that

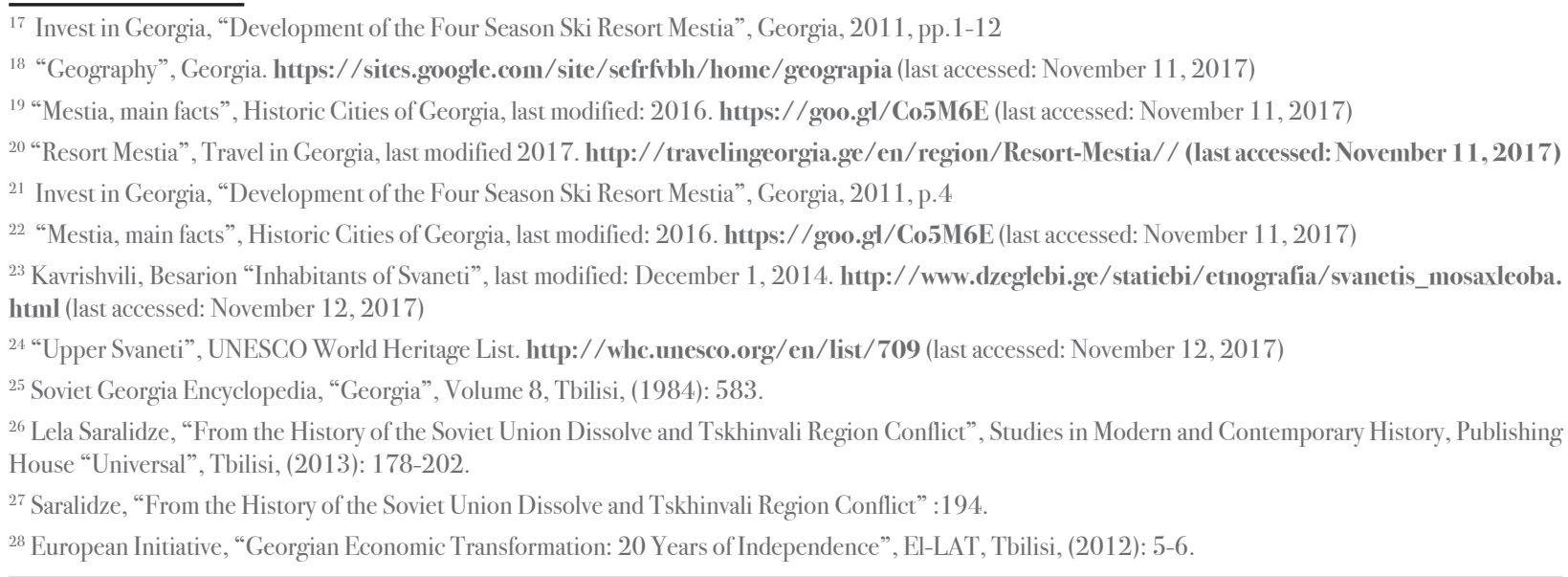


played as a third party in the civil war, on the side of the separatists. Public safety was one of the biggest issues.

Corruption and poverty level was in its peak. ${ }^{29}$

The existing political and economic environment prevented the country from having any type of tourism policy. Therefore, several years had to pass and the security state had to be stabilized in the country and damaged by war infrastructure to fix it to become attractive for international tourists. It took an overthrow of the first president of Georgia- Zviad Gamsakhurdia and several years of the administration of the ex-minister of foreign affairs of the Soviet Union- Eduard Shevardnadze as the second president, to reach the state of moderate readiness for tourism. ${ }^{30}$

After the Rose Revolution in 2003, the condition in Georgia started to gradually change. The new government implemented number of reforms that stimulated the political and economic improvements. As tourism was chosen as the focus, infrastructure projects were quickly approved and realized and an intensive promotion about the countries security and readiness to host tourist took place inside and outside of Georgia. ${ }^{31}$ The statistic figures of tourists visiting Georgia changed accordingly. ${ }^{32}$

The war between Russia and Georgia in 2008 and security issues resolved the country on the way to its successful tourism development. But it took only couple of years to get back on the track and continue the progress (see figure 1). ${ }^{33}$ Tourism has been developing steadily ever since in Georgia. ${ }^{34}$

\section{Mestia Comprehensive "Development Vision, General Planning and Specific Master Plan"}

Post August war period was very much devastating for Georgian tourism, economy and social condition. Therefore, the government cumulated all of its resources to quickly recover from the existing crisis. The international consultant "EcoSign - Mountain Resort Planners" Ltd, Canada and Geographic Georgia were commissioned to create Mestia’s Comprehensive “Development Vision, General Planning and Specific Master Plan”. The processes that would be coherently implemented would support to create and maintain tourist infrastructure. The goal was to rehabilitate the highway leading to Mestia, as well as inner city streets, to make tourist sites more accessible. The new Mestia airport was supposed to minimize the travel time from the capital to Svaneti. Improving communal infrastructure, such as water and sewage system was one of the main priorities aswell. ${ }^{35}$

The city center must have also been reconstructed and a development area had to be allotted for hotel and residential dwelling units close to the tourist attractions. Restoration and reconstruction project of the Svaneti Towers and new Mestia museum would support cultural tourism in the region, while creating Mestia ski resort would attract adventure tourists.

Intensive training in the field of service would take place, to prepare the staff of tourism to be qualified and suitable to international standards. Byimplementingall theabove-mentioned goals, Mestiawouldbecomeafour-seasontouristdestination. ${ }^{36}$

As all the activities foresaw an intensive involvement of local community in the process of implementation of the strategy, the plan turned out to be strongly sustainable. Keeping in mind the interests of the locals as main stakeholders were the key towards continuous success. Income of the Mestia inhabitants grew. A lot of them started family businesses in the field of tourism service and as the easy access made it possible to connect to Tbilisi, the main hub for international tourists, the visitors flow increased. If guided tours in Mestia museums were less than 1.000 per season, it increased up to 6000 by 2015, GDP doubled, and the distribution of total added value increased in most of the areas (see figures 2,3 and 4 ). ${ }^{37}$

Mestia tourism development strategy is a good example of how locals with their distinct culture and lifestyle can benefit from

\footnotetext{
${ }^{29}$ Anti-corruption State Department, "Chronical of the reforms implemented in Georgia", the World Bank, Washington DC, (2012): 3-5.

${ }^{30}$ Alexandre Gelovani, “Ups and Downs of Georgian Economy”, Sputnik Georgia, last modified: July 21, 2017. https://sputnik-georgia.com/ reviews/20170721/236709095/qartuli-konomikis-agmafrenebi-da-chavardnbi.html (last accessed: November 12, 2017)

${ }^{31}$ Neorgian National Tourism Administration, “Overview of Georgian Tourism Industry”, Georgia, (2012): 3-4.

32 “Georgian Tourism Development Strategy", Tasisi, Tbilisi, (2001): 21.

${ }^{33}$ Neorgian National Tourism Administration, “Overview of Georgian Tourism Industry”, Georgia, (2012): 4-5.

${ }^{34}$ Merab Janiashvili, "Tourism is the only sector in Georgia that progresses yearly”, BPI, last modified: April 19, 2017. http://bpi.ge/turizmi-ertadertiseqtoria-saqartvelos-ekonomikashi-romelic-yovelwliurad-izrdeba/ (last accessed: November 20, 2017).

${ }^{35}$ Invest in Georgia, “Development of The Four Season ski resort Mestia”, Georgia, (2011): 7-9.

${ }^{36}$ Invest in Georgia, "Development of The Four Season ski resort Mestia”: 7-9.

37 "GDP and Other Indicators of National Accounts", Georgian Statistics Office of Georgia, last modified: 2018. http://www.geostat.ge/index. php?action=page\&p_id=1 16\&lang=eng (last accessed: November 23, 2017).
} 
sustainable tourism. Not only they can get financial profit, but they can be the interpreters, storytellers and promoters of their own region. This way a small community realizes the importance of their uniqueness, preserves its traditions and customs at the place of its origin, and eagerly shares them with others. By doing so, locals can support country's economy and social condition and advertise it on the international level.

\section{Elephantine Island Case}

Having discussed the benefits of Culture Tourism, pointed out the advantages and disadvantages of it and dived into the concrete successful experience of Mestia sustainable tourism development plan, important conclusion can be drawn out that will be helpful to recommend a tourism development plan for the Elephantine Island in Aswan, Egypt.

The Island that stands out with its inhabitants' unique culture, traditions, archaeological evidence and the fact that it is an original place of dwelling has a great perspective to successfully develop a sustainable tourism strategy. For doing so, values of the site must be identified, and a general situational analysis has to be conducted. But firstly, it is important to briefly review the place.

\section{The Elephantine Island}

Elephantine Island is located on the opposite side of the city of Aswan in the Nile River in Upper Egypt about $885 \mathrm{~km}$ south from Cairo ${ }^{38}$ and $231 \mathrm{~km}$ from Abu Simbel. ${ }^{39}$ This small island that nowadays combines two Nubian villages: Koti and Siou ${ }^{40}$ was once the capital of the first Nome of Upper Egypt dating back to 3500 BC..$^{41}$ Nubians managed to preserve their traditions and customs for centuries. Their colorful houses mostly built with mud-bricks create a captivating view for visitors.

The people of the two villages (3500 to 5000 inhabitants) ${ }^{42}$ of Elephantine have settled in the central part of the island, with the ancient archaeological site on one end of the isle and a recently constructed luxurious hotel Mövenpick on the other end. Based on the observation and brief conversations with the locals, it can be assumed that most of the people working at the hotel are not necessarily Elephantine Nubians and the ones that are, are usually hired on low positions. The rest of the people work either as sailors, providing transportation from and to the island with a Felucca or a motor boat or in tourism sector- as tour guides.

The infrastructure of the Elephantine Island is in the critical state. There is no organized maintenance of the streets, garbage, water, or sewage system. Neither is there a structured transportation from and to the island. This will be a little surprise as the isle has not had an official mayor since the end of 1950s. Formally belonging to the Governorate of Aswan, it has a minimal stake of the governmentalbudget. ${ }^{43}$

\section{Situational Analysis}

The Elephantine Island, with its rich tangible and intangible heritage, has an immense potential to successfully carry out a sustainable tourism strategy that the locals can benefit from and use for maintaining not only the physical living environment, but also their customs and traditions. For doing so, it is crucial to fundamentally analyze the current situation on the island. Before shifting to SWOT analysis, key parties, or stakeholders must be identified to have a better understanding of who are the beneficiaries and benefactors. As the approach is sustainable, the key stakeholder is the local community, i.e. the Nubians of Elephantine. Institutions that have direct influence on the well-being of the island are the governmental parties, such as Aswan Governorate and ministries (Ministry of State of Antiquities, Ministry of Culture, Ministry of Environment, Ministry of Water Resources and Irrigation). There are a few International Governmental Organizations and Non-Governmental Organizations

\footnotetext{
38 "Distance from Cairo to Aswan", Distance Calculator. https://www.distancecalculator.net/from-cairo-to-aswan (last accessed: November 23, 2017).

39 "Distance Between Aswan and Abu Simbel”, Disween. http://disween.com/aswan-16-eg/ABS (last accessed: November 23, 2017).

40 "Elephantine Island", Elephantine, last modified: January 24, 2014. http://www.aswan-individual.com/html/eleph.html (last accessed: January 20, 2018)

${ }^{41}$ Esraa Alhadad, Maissa Moustafa Mariam Dawoud and Nesma Ahmed. "Elephantine Island. the Neglected Site. A case Study from Visitor Management Approach", Paper presented in the HCSM Fifth International Conference, (2018): 5.

${ }^{42}$ Alhadad "Elephantine Island. the Neglected Site. A case Study from Visitor Management Approach": 10.

${ }^{43}$ Ossama Abdel Meguid. Phone Interview, (23November 2017)
} 
that act in favor of the local community to implement social projects, to improve the current state of the isle inhabitants. ${ }^{44} \mathrm{German}$ Archaeological Institute, on the other hand, has been playing an important part in excavating, studying and researching the archaeological site on the island. ${ }^{45}$ As they have maintained the museum and the site, they have kept Elephantine attractive to the specific segment of visitors who are interested in history and archaeology. As the goal of this analysis is tourism developments, in the first place, private sector representatives who create tourism infrastructure must be named as key stakeholders as well. Therefore, both international and domestic tourists, local hotels, hostels and guesthouses, restaurants and cafes or tourism companies are not to be missed on this list.

To define the potential advantages and disadvantages of the island as a tourist destination, SWOT analysis tool will be used (see illustration 5). As shown on the illustration there are quite a few obstacles to deal with. It was already mentioned above that infrastructure maintenance is one of the main problem that the locals face. This issue also hinders the development of tourism friendly environment. Besides, tourist facilities and interpretation are weak and malfunctioning. As marketing and management plan is inexistent, there are no funds to support it. Threats, such as the political and economic state of Egypt also add to the challenges. Though the problems might seem complex, strength and opportunities can re-weigh them. Perfect geographic location, unique culture and traditions, authentically practiced customs, vernacular and colorful Nubian architecture, as well as UNESCO archaeological site are the strong points of Elephantine. As the two villages of the island managed to preserve their living heritage, it is a great place of adventurers and eco-tourists, who are willing to explore unspoiled, authentic living environment of unique people and their culture. The fact that the Nubians are open, friendly and hospitable, with the dwellings of traditional architecture, increases the attractiveness of the place for tourists to not only go to visit, but spend a night on the island with the locals. Thereby, Elephantine has the potential of turning into a destination.

\section{Goals and Strategies}

While setting a goal for developing tourism on the Elephantine Island, it is important to once more clarify the focus of the plan. The primary objective must be the maintenance of the tangible and intangible heritage of the local community. The stakeholders and the managers of the development process should be the Nubians as well. The strategy towards achieving the goal must be community oriented, thus sustainable.

The first step to take is to create a management plan that will consider all the weaknesses and threats and apply solutions to them, while evaluating the potential of the two villages as an adventure, eco- tourist destination. By combining all the factors, success can be achieved. For this reason, the voice of the locals has to be heard and they must be put in charge of the process, by supporting them with developing basic infrastructure, training them in tourism and service field and teaching them the ways of interpreting and presenting their customs.

\section{Managing Risks}

When talking about promoting a place such as Elephantine, as a tourist destination there are quite a few risk factors that should be kept in mind. Firstly, when talking about the uniqueness of the place because of its intact traditions that are still practiced there, the danger of losing this key card has to also be mentioned. Locals may falsify customs to present them to visitors in a way that they will be more easily accepted. This will contradict the sustainability concept, as, instead of maintaining their culture, the community will adjust it to tourists needs. Therefore, it is necessary to raise awareness within the community about the importance of their cultural authenticity.

Another problem is the tourist capacity of the site. As Elephantine Island itself is a small place, the number of visitors travelling there should be regulated if it becomes a mass tourism hot spot. This can be easily done by raising the price of Feluccas travelling from Aswan to the isle or setting an entrance fee on the island.

\section{Outcomes and Outputs}

If the above-mentioned suggestions are taken in consideration and the development plan is constructively implemented, it will become possible to create a sustainable chain between locals, their living traditions and tourists. The active exchange process between the community and the visitors will create beneficial environment for both sides. The Nubians will receive

\footnotetext{
44 "NGO Directory Aswan", A Capable Civil Society. http:/ / www.ngosportal.org/ngo-directory/-in-Governorates/Governorates/aswan (last accessed: November 20,2017).

${ }^{45}$ Esraa Alhadad, et al., (2018): 5, 7.
} 
regular income on behalf of their hospitality, culture and customs for the sake of the maintenance of those just mentioned. The Elephantine Island will turn into a destination, managed and organized by locals, for their own benefit. It will improve social and economic condition and decrease poverty. Meanwhile, the tourists will get a chance of experiencing unique living culture in the original place.

\section{Conclusion}

In conclusion, cultural heritage tourism is surely considered an innovative catalyst of local community development in any site. In addition, it's a golden key for the stakeholder cooperation that can easily achieve the "win- win" situation between all of them. It is considered a way to preserve the cultural heritage authenticity and integrity, flourish the tourism sector, develop the infrastructure and services of the site and finally develop the socio- economical level of the local people living in the area. That will always depend on the management plan that should be set up for the site according to the management of the available resources (economical, environmental, cultural and social), the level and the quality of the community in different types of the cultural and tourism activities.

Cultural heritage and tourism integration are essential for protecting the cultural property in one hand, while on the other hand involve the community in the tourism activities. For this reason, a need for changing the general standard of the stakeholder cooperation and networking to improve and develop the well- being of the residences in the touristic sites is extremely important. The main successful key is the community participation even in the planning processes. That will lead to building communication channels and enhancing the relationship between the community and the other key stakeholders to achieve the development project goals.

\section{Bibliography}

Alhadad, Esraa. "Stakeholder Involvement in Heritage Site Management”, Master Thesis, BTU- Cottbus, Germany and HU- Egypt, (2015).

Alhadad, Esraa, Moustafa,Maissa,Dawoud, Mariam,and Ahmed, Nesma. "Elephantine Island the Neglected Site. A case Study from Visitor Management Approach", Paper presented in the HCSM Fifth International Conference, (2018).

Alzua, Aurkene, T. O’Leary, Joseph and M. Morrison, Alastair. "Cultural and Heritage Tourism: Identifying niches for international travelers", The Journal of Tourism Studies 9, no. 2, (2009): 2- 13.

Anti-corruption State Department. "Chronical of the reforms implemented in Georgia”, The World Bank, Washington DC, (2012).

Ardahaey, Fateme. "Economic Impacts of Tourism Industry", International Journal of Business and Management 6, no. 8, (August 2011): 206- 215.

"Distance Between Aswan and Abu Simbel", Disween. http://disween.com/aswan-16-eg/ABS (last accessed: November 23, 2017).

"Distance from Cairo to Aswan", Distance Calculator. https://www.distancecalculator.net/fromcairo-to-aswan (last accessed: November 23, 2017).

"Elephantine Island", Elephantine, last modified: January 24, 2014. http://www.aswan-individual.com/html/eleph. html (last accessed: January 20, 2018).

"GDP and Other Indicators of National Accounts", Georgian Statistics Office of Georgia, last modified: 2018, http://www. geostat.ge/index.php?action=page\&p_id=116\&lang=eng (last accessed: November 23, 2017).

"Geography", Georgia, https://sites.google.com/site/sefrfvbh/home/geograpia (last accessed: November 11, 2017).

"Georgian Tourism Development Strategy", Tasisi, Tbilisi, (2001).

"Mestia, main facts", Historic Cities of Georgia, last modified: 2016. https://goo.gl/Co5M6E (last accessed: November 11, 2017).

Csapó, János. "The Role and Importance of Cultural Tourism in Modern Tourism Industry", in Kasimoglu, Murat (ed.), Strategies for Tourism Industry - Micro and Macro Perspectives,Hungary (2012): 201-232.

European Initiative, "Georgian Economic Transformation: 20 Years of Independence”, El-LAT, Tbilisi, (2012).

Fariborz,Aref. "Community Leaders' Perceptions toward Tourism Impacts and Level of Community Capacity Building in 
Tourism Development”, Journal of Sustainable Development 2, no. 3, (November 2009): 208- 213.

Geethika, Nayomi, W.K. AthulaGnanapala, “Socio-Economic Impacts on Local Community through Tourism Development with Special Reference to Heritance Kandalama”, Tourism, Leisure and Global Change2 (2015): TOC-57.

Gelovani, Alexsandre. "Ups and Downs of Georgian Economy", Sputnik Georgia, last modified: July 21, 2017. https:// sputnik-georgia.com/reviews/20170721/236709095/qartuli-konomikis-agmafrenebi-da-chavardnbi.html (last accessed: November 12, 2017).

ICOMOS Charter for Cultural Tourism, Draft (April 1997).

Invest in Georgia, "Development of The Four Season Ski Resort Mestia”, Georgia, (2011).

Janiashvili, Merab., "Tourism is the only sector in Georgia that progresses yearly”, BPI, last modified: April 19, 2017. http:// bpi.ge/turizmi-ertaderti-seqtoria-saqartvelos-ekonomikashi-romelic-yovelwliurad-izrdeba/ (last accessed: November 20, 2017).

Kavrishvili, Besarion.,"Inhabitants of Svaneti”, last modified: December 1, 2014. http://www.dzeglebi.ge/statiebi/ etnografia/svanetis_mosaxleoba.html (last accessed: November 12, 2017).

Lynn, Speno. (ed.), Heritage Tourism Handbook: A How-to-Guide for Georgia, Historic Preservation Division, (2010).

McNulty, Robert and Koff, Russell, “About partners for livable communities”, Washington, DC, (2014).

National Statistics Office of Georgia, "Tourism Statistics", last modified: 2018. http://www.geostat.ge/index. php?lang=geo (last accessed: November 10.01.2018).

Neorgian National Tourism Administration, "Overview of Georgian Tourism Industry”, Georgia, (2012).

"NGO Directory Aswan", A Capable Civil Society. http://www.ngosportal.org/ngo-directory/-in-Governorates/ Governorates/aswan (last accessed: November 20, 2017).

Ossama, Abdel Meguid. Phone Interview, (23November 2017).

"Resort Mestia", Travel in Georgia, last modified 2017. http://travelingeorgia.ge/en/region/Resort-Mestia// (last accessed: November 11, 2017).

Robinson, Mike and Picard, David. “Tourism, Culture and Sustainable Development, Programme” "Culture, tourism, development", Division of Cultural Policies and Intercultural Dialogue, Culture Sector, UNESCO, France, (2006).

Saralidze, L., "From the History of the Soviet Union Dissolve and Tskhinvali Region Conflict", Studies in Modern and Contemporary History, Publishing House "Universal”, Tbilisi, (2013): 178-202.

Slavov, Slavi. "Impacts of Tourism on The Local Community", Scientific Review of Physical Culture 5, issue 3, National Sports Academy "Bulgaria, 59.

Soviet Georgia Encyclopedia, “Georgia” 8, Tbilisi, (1984): 583.

Sunlu, Ugur. "Environmental Impacts of Tourism”, in Camarda D. (ed.), Grassini L. (ed.). Local resources and global trades: Environments and agriculture in the Mediterranean region, (2003): 263- 270.

Thryambakam, Potukuchi. "Impact of Tourism on Community Development and Sustainability in Maredumilli, East Godavari District of Andhra Pradesh- A Case Study”, Global Journal of Management and Business Studie 3, no. 9 (2013): 1013-1020. "Upper Svaneti”, UNESCO World Heritage List. http://whc.unesco.org/en/list/709 (last accessed: November 12, 2017).

Walter, Jamieson. The Challenges of Sustainable Community Cultural Heritage Tourism, Asian Institute of Technology, Bangkok, Thailand, (2000). 